\title{
Rhythm of the $\beta$-cell oscillator is not governed by a single regulator: multiple systems contribute to oscillatory behavior
}

\section{Emma Heart and Peter J. S. Smith}

Am J Physiol Endocrinol Metab 292:E1295-E1300, 2007. First published 9 January 2007;

doi:10.1152/ajpendo.00648.2006

You might find this additional info useful...

This article cites 41 articles, 18 of which can be accessed free at:

http://ajpendo.physiology.org/content/292/5/E1295.full.html\#ref-list-1

This article has been cited by 5 other HighWire hosted articles

Bursting and calcium oscillations in pancreatic $\beta$-cells: specific pacemakers for specific mechanisms

L. E. Fridlyand, N. Tamarina and L. H. Philipson

Am J Physiol Endocrinol Metab, October , 2010; 299 (4): E517-E532.

[Abstract] [Full Text] [PDF]

Role for malic enzyme, pyruvate carboxylation, and mitochondrial malate import in glucose-stimulated insulin secretion

Emma Heart, Gary W. Cline, Leon P. Collis, Rebecca L. Pongratz, Joshua P. Gray and Peter J.

S. Smith

Am J Physiol Endocrinol Metab 2009; 296 (6): E1354-E1362.

[Abstract] [Full Text] [PDF]

Effects of palmitate on ER and cytosolic $\mathrm{Ca}^{2+}$ homeostasis in $\beta$-cells Kamila S. Gwiazda, Ting-Lin B. Yang, Yalin Lin and James D. Johnson Am J Physiol Endocrinol Metab 2009; 296 (4): E690-E701.

[Abstract] [Full Text] [PDF]

Synchronizing $\mathrm{Ca}^{2+}$ and cAMP oscillations in pancreatic $\beta$-cells: a role for glucose metabolism and GLP-1 receptors? Focus on "Regulation of cAMP dynamics by $\mathrm{Ca}^{2+}$ and $\mathrm{G}$ protein-coupled receptors in the pancreatic $\beta$-cell: a computational approach"

George G. Holz, Emma Heart and Colin A. Leech

Am J Physiol Cell Physiol, January 1, 2008; 294 (1): C4-C6.

[Full Text] [PDF]

Metabolic and electrical oscillations: partners in controlling pulsatile insulin secretion

Richard Bertram, Arthur Sherman and Leslie S. Satin

Am J Physiol Endocrinol Metab, October 1, 2007; 293 (4): E890-E900.

[Abstract] [Full Text] [PDF]

Updated information and services including high resolution figures, can be found at:

http://ajpendo.physiology.org/content/292/5/E1295.full.html

Additional material and information about AJP - Endocrinology and Metabolism can be found at: http://www.the-aps.org/publications/ajpendo

This infomation is current as of May 27, 2011.

AJP - Endocrinology and Metabolism publishes results of original studies about endocrine and metabolic systems on any level of organization. It is published 12 times a year (monthly) by the American Physiological Society, 9650 Rockville Pike, Bethesda MD 20814-3991. Copyright @ 2007 by the American Physiological Society. ISSN: 0193-1849, ESSN: 1522-1555. Visit our website at http://www.the-aps.org/. 


\title{
Rhythm of the $\beta$-cell oscillator is not governed by a single regulator: multiple systems contribute to oscillatory behavior
}

\author{
Emma Heart and Peter J. S. Smith \\ BioCurrents Research Center, Molecular Physiology Program, Marine Biological Laboratory, Woods Hole, Massachusetts
}

Submitted 27 November 2006; accepted in final form 5 January 2007

Heart E, Smith PJS. Rhythm of the $\beta$-cell oscillator is not governed by a single regulator: multiple systems contribute to oscillatory behavior. Am J Physiol Endocrinol Metab 292: E1295-E1300, 2007. First published January 9, 2007; doi:10.1152/ajpendo.00648.2006.-Pulsatile insulin output, paralleled by oscillations in intracellular $\mathrm{Ca}^{2+}$, reflect oscillating metabolism within $\beta$-cells in response to secretory fuels. Here we question whether oscillatory periodicity is conserved or varied from stimulation to stimulation, whether glycolysis is essential for the manifestation of an oscillatory response, and if an environment of nutrient oversupply affects oscillatory regularity. We have determined that a $\beta$-cell oscillatory $\mathrm{Ca}^{2+}$ pattern is independent of the type of applied secretory fuel (glucose, methyl-pyruvate, or $\alpha$-ketoisocaproate). In addition, single cells respond with the same pattern when repeatedly stimulated, regardless of the type of stimulatory fuel. Presence of substimulatory glucose is not necessary to obtain an oscillatory responses to methyl-pyruvate or $\alpha$-ketoisocaproate. Glucose-6-phosphate, as a measure of glycolytic flux, is not detectable under these conditions. These data suggest that multiple systems, rather than a single enzyme component, can contribute to the $\beta$-cell oscillatory behavior. Prolonged exposure to high levels of palmitate impaired oscillatory regularity in the individual $\beta$-cells. This supports the hypothesis that a high-fat environment might contribute to loss of regular oscillatory pattern in diabetic subjects, acting, at least in part, at the level of the single $\beta$-cell.

insulin secretion; secretory fuels; $\mathrm{Ca}^{2+}$ oscillations

INSULIN RELEASE FROM THE PANCREAS is pulsatile $(11,20)$. The regular oscillatory pattern of insulin secretion, in contrast to a steady-state infusion, is important for a more functional hormone interaction with the peripheral tissues $(32,35)$ and has been reported to be impaired in Type 2 diabetic patients (1). The single $\beta$-cell is a metabolic oscillator, and it is widely accepted that, under in vitro conditions, such as isolated islets or single $\beta$-cells, oscillatory insulin secretion is a consequence of oscillations in cellular metabolism (19). Oscillation in $\beta$-cell metabolism leads to oscillations in the ATP-to-ADP ratio, which then drives oscillation in the activity of the ATPsensitive $\mathrm{K}^{+}$channels, leading to plasma membrane depolarization, $\mathrm{Ca}^{2+}$ influx, and insulin output (15). Oscillations in a variety of parameters, such as oxygen consumption, mitochondrial membrane potential, ATP-to-ADP ratio, and $\mathrm{Ca}^{2+}$ activity, have been reported in single clonal or primary $\beta$-cells (19), but what systems are responsible for the generation of these oscillations, as well as how these oscillations are affected by the nutrient environment, has not been clearly addressed. While individual $\beta$-cells have been shown to display different sensitivities to glucose (6), the issue of how an individual cell responds to repetitive fuel stimuli is not known.

Address for reprint requests and other correspondence: E. Heart, BioCurrents Research Center, Molecular Physiology, MBL, 7 MBL St., Woods Hole, MA 02543 (e-mail: eheart@mbl.edu).
Oscillatory glycolysis and the action of its proposed pacemaker, the allosteric enzyme phosphofructokinase (PFK), has been reported to take place in $\beta$-cells. It represents a singlecomponent model, according to which $\beta$-cell metabolic oscillations are an obligatory consequence of oscillatory glycolysis, governed by PFK $(17,43)$. We have tested this hypothesis by using nonglycogenic secretagogues in the absence of substimulatory glucose and measured levels of glycolytic flux under these conditions. We have found that $\beta$-cells display oscillations under conditions where nonglycogenic fuels are employed and glycolytic flux is absent. Furthermore, we have shown that a conserved periodicity is independent of fuel type. We have also determined how an environment of nutrient oversupply affects $\beta$-cell oscillatory behavior. Our study suggests that oscillatory metabolism is potentially underwritten by multiple components and is susceptible to modulation by the nutrient environment.

\section{METHODS}

Animals. Male Swiss-Webster mice (Charles River) were euthanized by halothane. All procedures were performed in accordance with the Institutional Guidelines for Animal Care, in compliance with United States Public Health Service regulations.

Islet isolation and primary cell culture. Pancreatic islets were isolated by collagenase (Roche) digestion, as previously described (13). Following overnight culture, islets were dispersed by incubation in $\mathrm{Ca}^{2+} / \mathrm{Mg}^{2+}$-free PBS containing $3 \mathrm{mM}$ EGTA and $0.002 \%$ trypsin for $10 \mathrm{~min}$ at $37^{\circ} \mathrm{C}$ with occasional agitation. Cells were centrifuged, washed, suspended in RPMI-1640 culture media (Sigma) supplemented with $5 \mathrm{mM}$ glucose, $10 \%$ fetal calf serum (HyClone), 100 $\mathrm{IU} / \mathrm{ml}$ penicillin, and $100 \mu \mathrm{g} / \mathrm{ml}$ streptomycin, and plated on poly-Dlysine-coated coverslips (MatTek, Ashland, MA) in 35-mm petri dishes $\left(\mathrm{Ca}^{2+}\right.$ studies) or 48 -well plates (secretion).

$\mathrm{Ca}^{2+}$ measurement. Single mouse islet cells were cultured for $72 \mathrm{~h}$ in the absence (control) or presence of $0.4 \mathrm{mM}$ palmitate (lipotoxicity). Cells were loaded for $30 \mathrm{~min}$ with $\mathrm{Ca}^{2+}$ indicator fluo-4-AM (Molecular Probes) in the growth media, washed in Krebs-Ringer bicarbonate (KRB) buffer ( $4 \mathrm{mM}$ glucose, $140 \mathrm{mM} \mathrm{NaCl}, 30 \mathrm{mM}$ HEPES, 4.6. $\mathrm{mM} \mathrm{KCl,} 1 \mathrm{mM} \mathrm{MgSO} 4,0.15 \mathrm{mM} \mathrm{Na}_{2} \mathrm{HPO}_{4}, 0.4 \mathrm{mM}$ $\mathrm{KH}_{2} \mathrm{PO}_{4}, 5 \mathrm{mM} \mathrm{NaHCO}, 2 \mathrm{mM} \mathrm{CaCl}$ and $0.05 \%$ BSA, pH 7.4, osmolarity $284 \mathrm{mosM}$ ), allowed to equilibrate for $15 \mathrm{~min}$, and imaged on Zeiss-510 confocal microscope equipped with a heated stage. Fluo-4 was excited using 488 line of argon laser. Images were taken every $10 \mathrm{~s}$. Both control and palmitate-treated cells were used for a single-step stimulation protocol with $10 \mathrm{mM}$ glucose to determine $\mathrm{Ca}^{2+}$ oscillatory regularity, which was calculated as standard deviation (SD) from the mean oscillatory period (OP) for that particular trace. Control cells were used for experimental series as follows. In the three-step protocol of series 1, glucose was raised from $4 \mathrm{mM}$ to stimulatory $10 \mathrm{mM}$ (step 1), lowered to $0 \mathrm{mM}$ (step 2), and raised to

The costs of publication of this article were defrayed in part by the payment of page charges. The article must therefore be hereby marked "advertisement" in accordance with 18 U.S.C. Section 1734 solely to indicate this fact. 
$10 \mathrm{mM}$ (step 3). [pH of the KRB buffer was not changed in the presence of $10 \mathrm{mM}$ methyl-pyruvate $(\mathrm{MeP})$ or $\alpha$-ketoisocaproate (KIC) for the duration of the experiment.] In series 2 and 3, MeP (10 $\mathrm{mM})$ or KIC (10 $\mathrm{mM})$, respectively, were applied in the absence of any glucose, in step 3. Scanning was paused in step 2 to minimize photodamage to the cells. Images were analyzed by the LSM Image Browser software to derive $\mathrm{Ca}^{2+}$ profiles. After the experiment, dishes were fixed in paraformaldehyde, and $\beta$-cells were identified using guinea pig anti-insulin antibody (Zymed, San Francisco, CA). Only insulin-positive ( $\beta$-cells) were included in the data analysis.

Insulin secretion. The amount of released insulin was determined after 30 min of static incubation with a radioimmunoassay kit (Linco Research, St. Charles, MO) using rat insulin as the standard.

Glucose 6-phosphate levels. Glucose 6-phosphate (G-6-P) levels were determined in TCA neutralized islet extracts by the cycling method of Lowry (22). Fifty to one-hundred islets per sample were used.

Materials. Unless otherwise indicated, all reagents were obtained from Sigma-Aldrich (St. Louis, MO).

\section{RESULTS}

The absence of substimulatory glucose during stimulation with nonglycogenic fuels $\mathrm{MeP}$ and $\mathrm{KIC}$ did not affect levels of insulin secretion (Fig. 1). Since it is established that the $\mathrm{Ca}^{2+}$ response and insulin output occur in parallel (15), we expected that the level of $\mathrm{Ca}^{2+}$ would not be affected by the absence of nonstimulatory glucose, and, therefore, we evaluated its oscillatory character under the same stimulatory conditions.

For $\mathrm{Ca}^{2+}$ studies, single cells were prepared from islets by dissociation and were subjected to the stimulation protocol that allowed us to determine how individual cells would respond to the repeated exposure of the same fuel (glucose), as well as second exposure to different fuels (KIC, MeP) in the absence of substimulatory glucose. The phenomenon of whether an individual cell will respond in the same or different manner to the repeated fuel challenge [a feature sometimes called "metabolic memory" (3)] has not been investigated before in $\beta$-cells. Individual $\beta$-cells responded to stimulatory fuel addition with a wide variety of $\mathrm{Ca}^{2+} \mathrm{OP}$ and lags (L), with average $\mathrm{OP}$ and $\mathrm{L}$ equal to $4.4 \pm 1.7$ and $4.1 \pm 1.4 \mathrm{~min}$, respectively. In individual $\beta$-cells, however, the second response was similar to the first (Fig. 2), as determined by comparison of the $\mathrm{L}$ and $\mathrm{OP}$ of the first and second $\mathrm{Ca}^{2+}$ response in the same cells for all fuel types $\left(\mathrm{L}_{2}=121 \pm 14 \%\right.$ of $\mathrm{L}_{1}, \mathrm{OP}_{2}=94 \pm 15 \%$ of

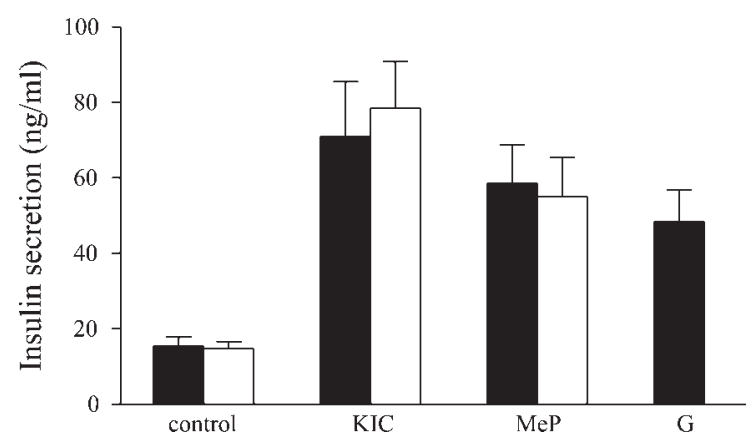

Fig. 1. Effect of substimulatory glucose on $\alpha$-ketoisocaproate (KIC)- and methyl-pyruvate (MeP)-dependent secretion. Mouse islets (10 islets/sample) were incubated for $30 \mathrm{~min}$, either without secretory fuels (control) or with 10 $\mathrm{mM}$ KIC, MeP, or glucose (G), in the presence (solid bar) or absence (open bar) of $4 \mathrm{mM}$ glucose. Data are average of 3 independent experiments, expressed as means $\pm \mathrm{SE}$.
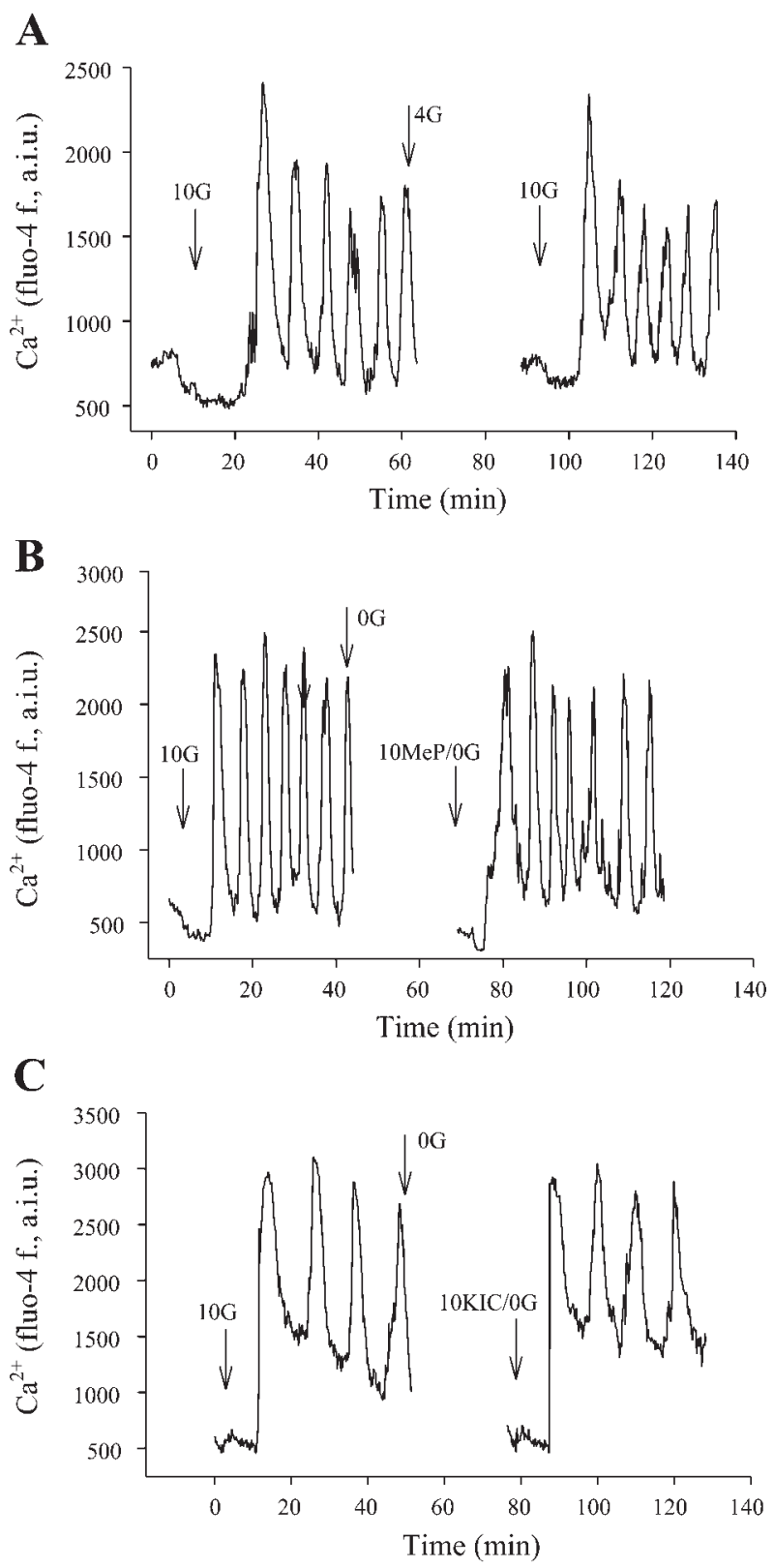

Fig. 2. $A, B$, and $C$ : examples of single $\beta$-cell $\mathrm{Ca}^{2+}$ responses to sequential challenge with stimulatory fuels $\mathrm{G}(n=33), \operatorname{MeP}(n=29)$, and $\mathrm{KIC}(n=26)$, where $n$ represents number of cells. Cells were challenged with 3 -step stimulation protocol, as described in METHODS. Additions of fuels are indicated by arrows. All cells examined behaved in a similar manner to these examples. aiu, Arbitrary intensity unit.

$\left.\mathrm{OP}_{1}, n=78\right)$. The response is thus conserved within an individual cell. This is further illustrated in Fig. 3, where the differences of $\mathrm{OP}_{2}-\mathrm{OP}_{1}$ are smaller when both OPs are calculated from an individual cell $(A)$, compared with the large values of $\mathrm{OP}_{2}-\mathrm{OP}_{1}$ when $\mathrm{OP}_{2}$ is calculated as an average from the rest of the cell population $(B)$. This effect occurred, regardless of the type of secondary fuel, as is apparent from Fig. 2, $B$ and $C$, which also illustrate that the absence of substimulatory (4 $\mathrm{mM}$ ) glucose did not prevent oscillations following the application of the nonglycogenic fuels MeP and KIC. In these experiments, after recordings were obtained in the presence of stimulatory $10 \mathrm{mM}$ glucose, cells were washed three times in 

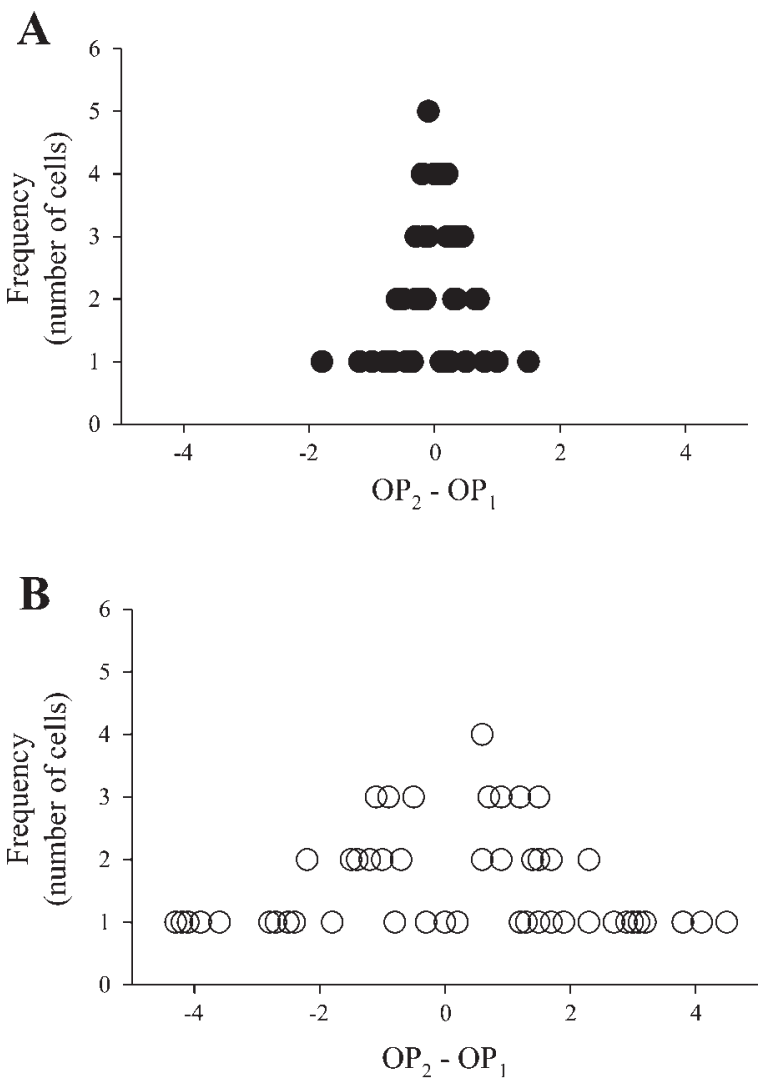

Fig. 3. Oscillatory responses in single cells are conserved and fuel-type independent. Differences are shown between the first $\left(\mathrm{OP}_{1}\right)$ and second oscillatory periods $\left(\mathrm{OP}_{2}\right)$, where both $\mathrm{OP}_{1}$ and $\mathrm{OP}_{2}$ are calculated from the same individual cell $(A ; \bullet)$ or where $\mathrm{OP}_{2}$ is calculated as an average from the rest of cells $(B ; \bigcirc) ; n=78$.

$\mathrm{KRB}$, with no glucose, and allowed to downregulate in this buffer for $30 \mathrm{~min}$ before the application of the stimulatory concentration of the second fuel. Nonstimulatory levels of both fuels $(1 \mathrm{mM})$ were included during this period, providing cells with a carbon source. To ascertain that, under these experimental conditions, glycolysis did not take place, G-6- $P$ levels, as a measure of glycolytic flux, were determined in islets maintained for $30 \mathrm{~min}$ in 0,4 , and $10 \mathrm{mM}$ glucose in the presence or absence of $10 \mathrm{mM}$ MeP or KIC, by the Lowry cycling method. Data presented in Table 1 demonstrate that no glycolytic flux was detected when islets were maintained in the absence of extracellular glucose. This is consistent with the fact that islets lack gluconeogenic phosphoenolpyruvate car-

Table 1. G-6-P levels in mouse islets

\begin{tabular}{cccc}
\hline \hline Glucose, $\mathrm{mM}$ & & $\mathrm{MeP}$ & KIC \\
\hline 0 & $\mathrm{ND}$ & $\mathrm{ND}$ & $\mathrm{ND}$ \\
4 & $0.55 \pm 0.06$ & $0.75 \pm 0.09$ & $0.62 \pm 0.04$ \\
10 & $1.56 \pm 0.25$ & $1.64 \pm 0.35$ & $1.46 \pm 0.28$ \\
20 & $2.6 \pm 0.34$ & $2.52 \pm 0.34$ & $2.83 \pm 0.18$ \\
\hline
\end{tabular}

Values, presented as pmol glucose 6-phosphate (G-6-P)/islet, are means \pm $\mathrm{SE}$ from 3 independent experiments. Islets (50) were exposed for $30 \mathrm{~min}$ to various glucose concentrations $(0-20 \mathrm{mM})$ in the presence or absence of 10 $\mathrm{mM}$ methyl-pyruvate (MeP) or $\alpha$-ketoisocaproate (KIC). G-6-P levels were measured in islet extracts as described in METHODS. ND, not detected. boxykinase and, therefore, would not be able to synthesize glucose $(26,29)$.

Next, we examined how oscillatory regularity is affected under a lipotoxic condition, which was induced by incubating the cells in the $0.4 \mathrm{mM}$ palmitate for $72 \mathrm{~h}$. Cells were then downregulated for $3 \mathrm{~h}$ in the normal medium, and the stimulatory protocol included a single-step jump from 4 to $10 \mathrm{mM}$ glucose. Palmitate exposure resulted in a decrease in the number of cells exhibiting oscillatory response (56 vs. $73 \%$ in control group), as well as a decreasing regularity of the response in those cells that retained a capacity to oscillate. Examples of a regular vs. irregular oscillatory response are presented in Fig. 4, $A$ and $B$. Regularity was calculated as the

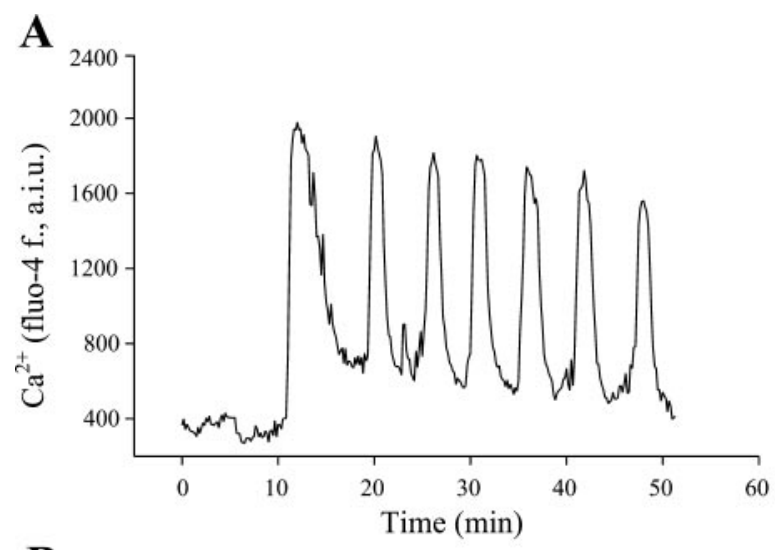

B
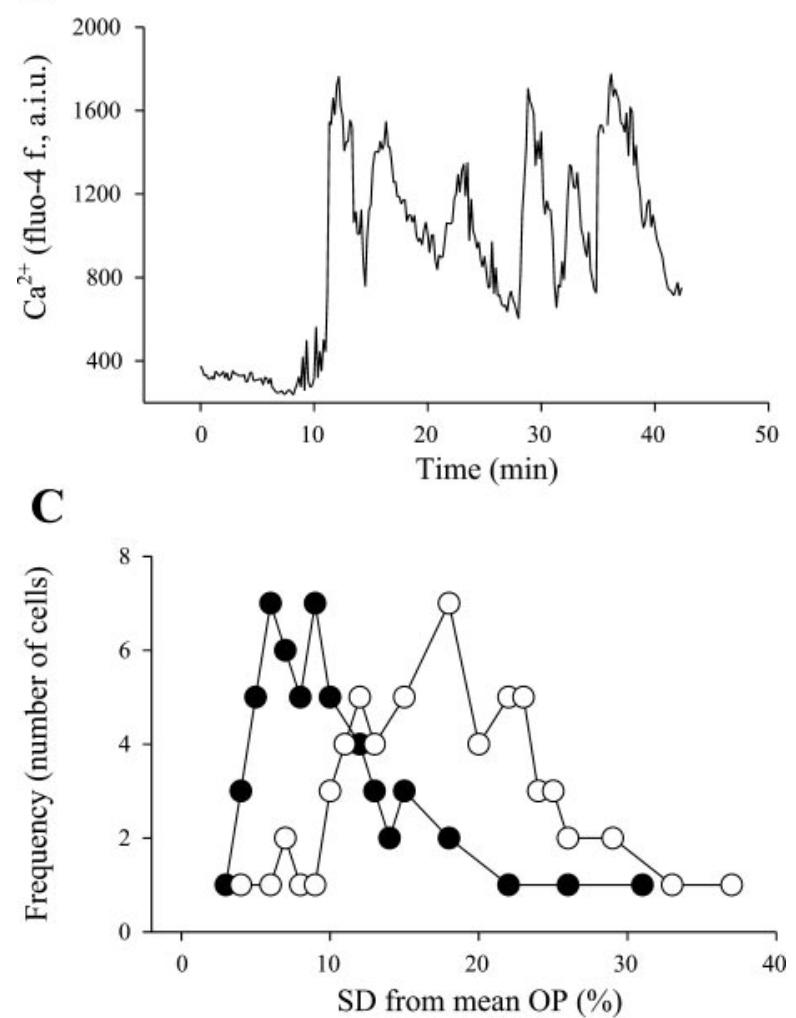

Fig. 4. Effect of palmitate exposure on oscillatory regularity in individual $\beta$-cells. Cells were cultured in the absence (example in $A, \bullet$ in $C, n=56$ ), or presence of $0.4 \mathrm{mM}$ palmitate (example in $B, \bigcirc$ in $C, n=60$ ) for $72 \mathrm{~h}$. $C$ : oscillatory regularity is expressed as standard deviation (SD) from the average oscillatory period calculated for each cell. 
standard deviation from the average OP. Figure $4 C$ illustrates that regularity of fuel-induced oscillations was impaired after cell culture in palmitate, compared with the control.

\section{DISCUSSION}

We have shown for the first time that individual $\beta$-cell oscillatory response to stimulatory levels of fuels is conserved and fuel-type independent within a single $\beta$-cell and, therefore, likely reflects a metabolic setting characteristic for the cell. We have further shown that these oscillations can occur via glycolysis-independent pathways, and that their oscillatory regularity is affected by saturated fatty acids.

Factors that drive and regulate oscillations in the $\beta$-cell metabolism remain under investigation. A model of glycolytic oscillations, as a driving force behind $\beta$-cell metabolic oscillations and ultimately insulin secretion, has been proposed (17, 43). According to this model, the allosteric enzyme PFK ( $\mathrm{PFK}_{\mathrm{m}}$, muscle type) is proposed to be the sole pacemaker of metabolic oscillations in the $\beta$-cell (44) and is under the regulatory control of a variety of substrates, including citrate and ATP. This forms a negative feedback loop, which generates pulsatile delivery of the glycolytic product pyruvate to the TCA cycle, resulting in oscillation of oxygen consumption and the ATP-to-ADP ratio (4). Oscillations in the ATP-to-ADP ratio then cause oscillations in the activity of the ATP-sensitive $\mathrm{K}^{+}$channels, which leads to the oscillatory $\mathrm{Ca}^{2+}$ influx and insulin secretion (15). Studies that report impairment of oscillation in subjects with a deficiency in $\mathrm{PFK}_{\mathrm{m}}$ seem to support a role for this enzyme (38). However, in the latter study, only two subjects were evaluated, and, although observed patterns were irregular, oscillations were still apparent. It is not known at present what residual amount of PFK is sufficient to drive glycolytic oscillations. Taking into account that this enzyme is relatively abundant, only a fraction might be sufficient to contribute to the maintenance of the oscillatory glycolysis. This issue is complicated by the fact that disappearance of the oscillatory response in $\beta$-cells, from islet-specific $P_{F K}$ knockout model, has not been demonstrated. As a consequence of the singular importance given to the role of PFK, the above model must assume that all other metabolic downstream processes are nonoscillatory. This is unlikely, as shown in reports describing oscillations in citrate (28) and in mitochondrial enzymes (25) in isolated $\beta$-cell mitochondrial preparations, a system devoid of glycolysis, as well as oscillations in $\beta$-cell metabolism in response to hormone stimulation $(7,12)$. In mathematical models, other factors besides glycolysis, such as ionic fluxes $(8,9,34)$, have been proposed to play an important role in the oscillatory response. The hypothesis that the oscillatory pattern is a result of multicomponent phenomena, and not just under the control of one single enzyme, has been proposed elsewhere $(36,42)$ and is consistent with the fact that all nonlinear systems operating far away from the equilibrium, such as enzymatic reactions, display oscillations $(10,18)$. In yeast, where oscillations in glycolysis were first described (2), it has been suggested that glycolytic control, confined solely to PFK, is not sufficient to account for metabolic oscillations (37) and that control of oscillations is distributed over a number of molecular processes (41).

In several studies, the effect of various secretagogues, with and without the presence of substimulatory glucose, on secre- tion and oscillatory metabolism has been investigated, and reported results vary greatly. In some studies, KIC, MeP, glyceraldehyde, and dihydroxyacetone were reported to be unable to elicit $\mathrm{Ca}^{2+}$ oscillations alone (17) or with glucose present $(5,21)$. In other reports, KIC induced slow $\mathrm{Ca}^{2+}$ oscillations (31) and secretion in the absence of substimulatory glucose $(14,40)$, which agrees with our data. In some of these studies, the nonglycogenic substrate $(\mathrm{MeP})$ was applied in a concentration $(20 \mathrm{mM})$ (5) that has been shown to block secretion (30), making it difficult to interpret such data. Some secretagogues, such as glyceraldehyde, have been shown to be toxic and not metabolized via the glycolytic pathway to an extent proposed earlier (27), and fuels such as pyruvate or succinate are not membrane permeable and, as such, would not stimulate metabolism in contrast to their methylated analogs (24). In many of these studies, secretion was not measured in parallel to ensure that the fuel concentration used was indeed stimulatory.

The character of the oscillatory response to stimulatory fuels in whole islets, as well as in single-cell preparations, may depend on the quality of the isolation procedure, as a consequence of which some cells or islets will establish oscillations, whereas others will not. Indeed, dispersion of the islets into the single cells results in $>50 \%$ cell death (16) and likely affects the integrity of the plasma membrane of some living $\beta$-cells, a feature crucial for demonstrating oscillations. It is, therefore, of a critical importance to establish that a cell or islet retained its capacity to respond to fuels in an oscillatory manner, before making a conclusion whether a particular fuel can produce oscillatory response. Only in a few studies have the same cells or islets been challenged sequentially with glucose and nonglycogenic fuel, making sure that such a system has the capacity to oscillate.

It might be argued that, in the absence of extracellular glucose, additional glucose can be provided to the $\beta$-cells through glycogenolysis. Thus the glycogen-derived glucose could enable glycolytic flux via PFK. It is unknown, however, what would be the time frame of glycogen mobilization, if this process indeed takes place. To exclude this possibility, and prove beyond a reasonable doubt that glycolytic flux was absent under conditions when MeP or KIC were used, G-6- $P$ levels were measured in the whole islets under the same conditions used for $\mathrm{Ca}^{2+}$ studies. While levels of G-6-P in cells cultured in the presence of stimulatory $(10 \mathrm{mM})$ or substimulatory $(4 \mathrm{mM})$ glucose were detectable, and in general agreement with the data reported before (33), we did not detect G-6- $P$ in the samples cultured in the absence of glucose. This confirms that, under these conditions, glycolytic flux is below detectable levels and, therefore, unlikely to influence metabolism.

Our data suggest that, although it is an indisputable fact that oscillatory glycolysis has a role and contributes to the generation of the metabolic oscillations when stimulatory glucose is applied, there are alternatives to drive the $\beta$-cell oscillations. Providing nonglycogenic fuels in the absence of substimulatory glucose directly demonstrates that an oscillatory capacity is preserved and conserved under the conditions when glycolytic flux is absent. This implies that the determinants of oscillatory frequency are downstream of these metabolic effectors.

Impairment of the regular oscillatory output has been described in Type 2 diabetic subjects (1), and the high-fat diet, 
resulting in the increased level of circulating saturated fatty acids, has been implicated in the development of Type 2 diabetes (23). It has been established that prolonged exposure to high levels of elevated fatty acids (a condition termed lipotoxicity) decreases glucose-stimulated insulin secretion in isolated islets (39). How lipotoxicity affects the oscillatory character of the response has not been addressed. The final oscillatory profile likely reflects a hierarchy involving 1 ) single $\beta$-cell oscillator, 2) synchronization of the single $\beta$-cells inside an islet, and 3) synchronization of islets, or at least population of islets, through the pancreas, which happens most likely via the nervous system. Although it is possible that all or at least one level must be involved, we investigated single $\beta$-cell oscillatory response after $72 \mathrm{~h}$ of palmitate culture. Palmitate exposure impaired regularity of the oscillatory response in these cells. This suggests that high-fat diet contributes to a loss of oscillatory regularity, at least at the single-cell level.

Altogether, our data show that the generation in $\beta$-cell metabolic oscillations is potentially a result of multiple factors and is affected by the nutrient environment.

\section{ACKNOWLEDGMENTS}

We thank Professor M. Meow for helpful comments and support in manuscript preparation.

\section{GRANTS}

These studies were supported by National Institutes of Health Grants P41RR-001395 and DK-063984 (to P. J. S. Smith).

\section{REFERENCES}

1. Bergsten P. Pathophysiology of impaired pulsatile insulin release. Diabetes Metab Res Rev 16: 179-191, 2000.

2. Betz A, Chance B. Phase relationship of glycolytic intermediates in yeast cells with oscillatory metabolic control. Arch Biochem Biophys 109: 585-594, 1965.

3. Carpinelli AR, Curi R, Malaisse WJ. Long-term regulation of pancreatic B-cell responsiveness to D-glucose by food availability, feeding schedule, and diet composition. Physiol Behav 52: 1193-1196, 1992.

4. Civelek VN, Deeney JT, Fusonie GE, Corkey BE, Tornheim K. Oscillations in oxygen consumption by permeabilized clonal pancreatic beta-cells (HIT) incubated in an oscillatory glycolyzing muscle extract. Diabetes 46: 51-56, 1997.

5. Dahlgren GM, Kauri LM, Kennedy RT. Substrate effects on oscillations in metabolism, calcium and secretion in single mouse islets of Langerhans. Biochim Biophys Acta 1724: 23-36, 2005.

6. DeVargas LM, Sobolewski J, Siegel R, Moss LG. Individual beta cells within the intact islet differentially respond to glucose. J Biol Chem 272: 26573-26577, 1997.

7. Dyachok O, Isakov Y, Sagetorp J, Tengholm A. Oscillations of cyclic AMP in hormone-stimulated insulin-secreting beta-cells. Nature 439: 349-352, 2006

8. Fridlyand LE, Ma L, Philipson LH. Adenine nucleotide regulation in pancreatic beta-cells: modeling of ATP/ADP-Ca ${ }^{2+}$ interactions. Am J Physiol Endocrinol Metab 289: E839-E848, 2005.

9. Fridlyand LE, Tamarina N, Philipson LH. Modeling of $\mathrm{Ca}^{2+}$ flux in pancreatic beta-cells: role of the plasma membrane and intracellular stores. Am J Physiol Endocrinol Metab 285: E138-E154, 2003.

10. Goldbeter A, Dupont G. Allosteric regulation, cooperativity, and biochemical oscillations. Biophys Chem 37: 341-353, 1990.

11. Goodner CJ, Walike BL, Koerker DJ, Ensinck JW, Brown AC, Chideckel EW, Palmer J, Kalansyk L. Insulin, glucagon, and glucose exhibit synchronous sustained oscillations in fasting monkeys. Science 195: 177-179, 1977.

12. Harbeck MC, Chepurny O, Nikolaev VO, Lohse MJ, Holz GG, Roe MW. Simultaneous optical measurements of cytosolic $\mathrm{Ca}^{2+}$ and cAMP in single cells. Sci STKE 353: 16, 2006.

13. Heart E, Corkey RF, Wikstrom JD, Shirihai OS, Corkey BE. Glucosedependent increase in mitochondrial membrane potential, but not cyto- plasmic calcium, correlates with insulin secretion in single islet cells. Am J Physiol Endocrinol Metab 290: E143-E148, 2006.

14. Hedeskov C. Mechanism of glucose-induced insulin secretion. Physiol Rev 60: 442-509, 1980.

15. Henquin JC. Triggering and amplifying pathways of regulation of insulin secretion by glucose. Diabetes 49: 1751-1760, 2000.

16. Idahl LA, Lernmark A, Sehlin J, Taljedal IB. The dynamics of insulin release from mouse pancreatic islet cells in suspension. Pflügers Arch 366: 185-188, 1976.

17. Juntti-Berggren L, Webb DL, Arkhammar PO, Schultz V, Schweda EK, Tornheim K, Berggren PO. Dihydroxyacetone-induced oscillations in cytoplasmic free $\mathrm{Ca}^{2+}$ and the ATP/ADP ratio in pancreatic beta-cells at substimulatory glucose. J Biol Chem 278: 40710-40716, 2003.

18. Kaiser F. External signals and internal oscillation dynamics: principal aspects and response of stimulated rhythmic processes. In: Self-Organized Biological Dynamics and Nonlinear Control, edited by Wallezcek J. Cambridge, UK: Cambridge University Press, 2000.

19. Kennedy RT, Kauri LM, Dahlgren GM, Jung SK. Metabolic oscillations in $\beta$-cells. Diabetes 51: S152-S161, 2002.

20. Lang DA, Matthews DR, Peto J, Turner RC. Cyclic oscillations of basal plasma glucose and insulin concentrations in human beings. $N$ Engl J Med 301: 1023-1027, 1979.

21. Lenzen S, Lerch M, Peckmann T, Tiedge M. Differential regulation of $\left[\mathrm{Ca}^{2+}\right]_{\mathrm{i}}$ oscillations in mouse pancreatic islets by glucose, alpha-ketoisocaproic acid, glyceraldehyde and glycolytic intermediates. Biochim Biophys Acta 1523: 65-72, 2000.

22. Lowry OH, Passonneau JV. A collection of metabolite assays. In: A Flexible System of Enzymatic Analysis. New York: Academic, 1972, p. 179-182.

23. Ma Y, Olendzki BC, Hafner AR, Chiriboga DE, Culver AL, Andersen VA, Merriam PA, Pagoto SL. Low-carbohydrate and high-fat intake among adult patients with poorly controlled type 2 diabetes mellitus. Nutrition 22: 1129-1136, 2006.

24. MacDonald MJ. Metabolism of the insulin secretagogue methyl succinate by pancreatic islets. Arch Biochem Biophys 300: 201-205, 1993.

25. MacDonald MJ, Al-Masri H, Jumelle-Laclau M, Cruz MO. Oscillations in activities of enzymes in pancreatic islet subcellular fractions induced by physiological concentration of effectors. Diabetes 46: 19962001, 1996.

26. MacDonald MJ, Chang CM. Do pancreatic islet contain significant amount of phosphoenolpyruvate carboxykinase or ferroactivator activity? Diabetes 34: 246-250, 1985.

27. MacDonald MJ, Chaplen FW, Triplett CK, Gong Q, Drought H. Stimulation of insulin release by glyceraldehyde may not be similar to glucose. Arch Biochem Biophys 447: 118-126, 2006.

28. MacDonald MJ, Fahien LA, Bus JD, Noaman MH, Fallon MJ, Kendrick MA. Citrate oscillates in liver and pancreatic beta cell mitochondria and in INS-1 insulinoma cells. J Biol Chem 278: 51894-51900, 2003.

29. MacDonald MJ, McKenzie DI, Walker TM, Kaysen JH. Lack of glyconeogenesis in pancreatic islets: expression of gluconeogenic enzyme genes in islets. Horm Metab Res 24: 158-160, 1992.

30. Malaisse W, Jijakli H, Ulusoy S, Cook L, Best L, Vinambres C, Villanueva-Penacarrillo M, Valverde I, Sener A. Insulinotropic action of methylpyruvate: secretory, cationic, and biosynthetic aspects. Arch Biochem Biophys 335: 229-244, 1996.

31. Martin F, Sanchez-Andres JV, Soria B. Slow $\left[\mathrm{Ca}^{2+}\right]_{i}$ oscillations induced by ketoisocaproate in single mouse pancreatic islets. Diabetes 44 : 300-305, 1995.

32. Matthews DR, Naylor BA, Jones RG, Ward GM, Turner RC. Pulsatile insulin has greater hypoglycemic effect than continuous delivery. Diabetes 32: 617-621, 1993.

33. Montague W, Taylor KW. Islet-cell metabolism during insulin release. Biochem J 115: 257-262, 1969.

34. Nunemaker CS, Bertram R, Sherman A, Tsaneva-Atanasova K, Daniel CR, Satin LS. Glucose modulates $\left[\mathrm{Ca}^{2+}\right]_{i}$ oscillations in pancreatic islets via ionic and glycolytic mechanisms. Biophys J 91: 2082-2096, 2006.

35. Paolisso G, Scheen AJ, Giugliano D, Sgambato S, Albert A, Varricchio M, D'Onofrio F, Lefebvre PJ. Pulsatile insulin delivery has greater metabolic effects than continuous hormone administration in man: importance of pulse frequency. J Clin Endocrinol Metab 72: 607-615, 1991.

36. Reijenga KA, van Megen YM, Kooi BW, Bakker BM, Snoep JL, van Verseveld HW, Westerhoff HV. Yeast glycolytic oscillations that are not 
controlled by a single oscillophore: a new definition of oscillophore strength. J Theor Biol 232: 385-398, 2005.

37. Reijenga KA, Teusink H, van Verseveld HW, Snoep JL, Westerhoff HV. Biothermokinetics in the post genomic era. In: Proceedings of the 8th International Meeting on Biothermokinetics, edited by Larsson C, Pahlman IL, Gustafsson L, Gothenberg, Sweden: Chalmers Reproservice, 1998, p. $593-718$.

38. Ristow M, Carlqvist H, Hebinck J, Vorgerd M, Krone W, Pfeiffer A, Muller-Wieland D, Ostenson CG. Deficiency of phosphofructo-1-kinase/muscle subtype in humans is associated with impairment of insulin secretory oscillations. Diabetes 48: 1557-1561, 1999.

39. Robertson RP, Harmon J, Tran PO, Poitout V. Beta-cell glucose toxicity, lipotoxicity, and chronic oxidative stress in type 2 diabetes. Diabetes 53: S119-S124, 2004.
40. Sener A, Malaise WJ. Nutrient metabolism in islet cells. Experientia 40: 1026-1035, 1984.

41. Teusink B, Bakker BM, Westerhoff HV. Control of frequency and amplitude is shared by all enzymes in three models for yeast glycolytic oscillations. Biochim Biophys Acta 1275: 204-212, 1996.

42. Teusink B, Westerhoff HV. 'Slave' metabolites and enzymes. A rapid way of delineating metabolic control. Eur J Biochem 267: 1889-1893, 2000.

43. Tornheim K. Are metabolic oscillations responsible for normal oscillatory insulin secretion? Diabetes 46: 1375-1380, 1997.

44. Yaney GC, Schultz V, Cunningham BA, Dunaway GA, Corkey BE, Tornheim K. Phosphofructokinase isoenzymes in pancreatic islets and clonal beta-cells (INS-1). Diabetes 44: 1285-1289, 1995.

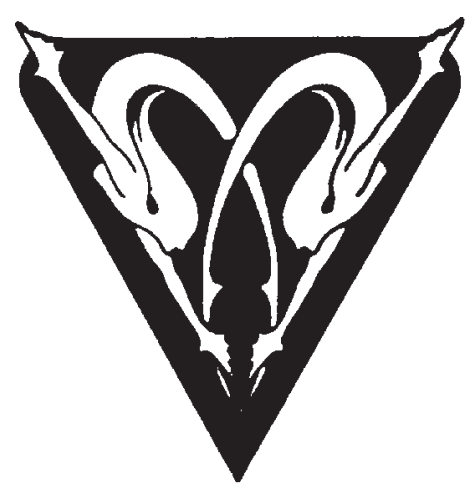

